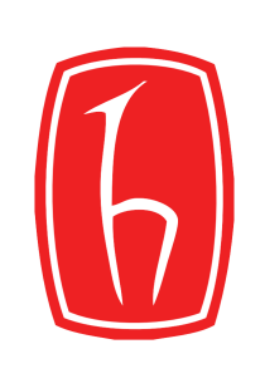

Hacettepe Üniversitesi Edebiyat Fakültesi Dergisi

Hacettepe University Journal of Faculty of Letters

Haziran/June 2019 - 36(1), 110-121

doi: $10.32600 /$ huefd.469147

Hakemli Makaleler - Refereed Articles

Geliş tarihi / Received: 10.10.2018 Kabul tarihi / Accepted: 06.12.2018

\title{
Shakespeare'in Hamlet Oyununda Çürümüşlük ve Hastalık İzlekleri ve İmgeleri
}

\author{
The Themes and Images of Decay and Disease in Shakespeare's Hamlet
}

\section{A. Deniz BOZER*}

\begin{abstract}
$\ddot{\mathbf{O z}}$
Bu çalışmanın amacı William Shakespeare'in on dördüncü yüzyılda Danimarka'da geçen Hamlet trajedisinde yazarın vurguladığı çürümüşlük ve hastalık izlekleri yanında görsel ve kokuyla ilgili imgeler yoluyla başta devlet olmak üzere, bireylerdeki ve doğadaki çürümüşlük ve hastalık imgelerini ele almaktır. Body politic (devlet) ve body natural (insan bedeni) arasındaki ilişki ortaya konup, devletteki yozlaşmanın kral olan ağabeyini öldürüp, başa geçen ve onun karısıyla evlenen Kral Claudius'daki ahlaki yozlaşmayla ne denli ilintili olduğu saptanmaktadır. Bunun yanı sıra Hamlet, Gertrude, Polonius, Laertes ve Ophelia karakterlerindeki bedensel, ruhsal ve ahlaki yozlaşmaizlekleri çürümüşlük ve hastalık imgeleri yoluyla tartışılmaktadır. Oyundaki tüm çürümüşlük ve kokuşmuşluğa karşın bir çiçek olarak betimlenen Ophelia'nın saraydakilere dağıttı̆̆ çiçeklerin simgesel anlamı üzerinde durulmaktadır. Ayrıca, devletteki ve bireylerdeki yozlaşmanın doğadaki yansımaları örneklenmektedir. Yakın okuma yöntemiyle anılan tiyatro oyunu metni söz konusu izlekler ve imgeler bağlamında yorumlanmakta ve Hamlet'in on yedinci yüzyılın başında Kraliçe I. Elizabeth'in iktidarının son zamanlarında İngiltere'deki sosyo-politik ortamı bir ölçüde yansittığı ortaya konmaktadır.
\end{abstract}

Anahtar sözcükkler: Shakespeare, Hamlet, çürümüşlük imgeleri, hastalık imgeleri, I. Elizabeth iktidarı

\begin{abstract}
The setting of William Shakespeare's Hamlet is fourteenth-century Denmark where the dramatist foregrounds themes and images of decay and disease through visual and olfactory imagery in the state itself, the king's court and nature. Establishing the relationship between body politic and body natural, how the moral corruption of King Claudius, who has murdered his brother, usurped the throne and married his wife, reflects upon the state of Denmark. In addition, the physical, mental and moral corruption in characters such as Hamlet, Gertrude, Polonius, Laertes and Ophelia will be examined in relation to the above-mentioned themes and images. Despite all the decay and corruption throughout the play, the symbolic significance of the flowers Ophelia appropriately gives to the members of the court will be analysed. Furthermore, how decay and disease in the state and in individuals impact nature will be posited. Applying close reading, the play will be interpreted in relation to themes and images of decay and disease with the aim of establishing how all these reflect upon the the socio-political condition of the court of Elizabeth I in the very early years of the seventeenth century.
\end{abstract}

Keywords: Shakespeare, Hamlet, images of decay, images of disease, the court of Elizabeth

\footnotetext{
* Profesör, Dr. Hacettepe Üniversitesi, Edebiyat Fakültesi, İngiliz Dili ve Edebiyatı Bölümü, e-posta: dbozer@ hacettepe.edu.tr ORCID: 0000-0002-8434-6468
} 


\section{Giriş}

William Shakespeare'in (1564-1616) Danimarka Prensi Hamlet 'in Trajik Hikâyesi adlı oyununun ilk basımı 1603 'de yapılmıştır. Ancak, oyunun ne zaman kaleme alındığı ve ne zaman ilk kez sahnelendiği hakkında kesin bir bilgi yoktur. Ne var ki, genel kanı Hamlet'in Shakespeare otuzlu yaşlarının ortalarındayken on altıncı yüzyılın sonunda ve on yedinci yüzyılın hemen başında, 1598 ile 1602 arasında, bir tarihte yazıldığı ve ilk kez 1601'de sahnelenmiş olabileceği doğrultusundadır. İlginçtir ki Hamlet'in ilk sahnelenişine dair tek kesin kayıt 1607 tarihlidir ve oyunun Batı Afrika kıyılarında bir gemide sahnelendiğini belgelemektedir (Thompson ve Taylor, 1996, s. 55).

Shakespeare'in pek çok oyununda olduğu gibi Hamlet'te de konu özgün değildir ve başka kaynaklardan alınmıştır. Hamlet’tekikişi ve olaylar büyük ölçüde Danimarkalı dilbilgisi uzmanı Saxo Grammaticus'un (c. 1150 - c. 1220) Latince yazılmış olan Gesta Danorum (Danimarkalıların Kahramanlık Hikâyeleri) adlı on altı ciltlik kitabının üçüncü ve dördüncü ciltlerinde yer alan ve gerçek tarihî olaylara dayanan Vita Amlethi'den (Amleth'in Yaşamı) alınmıştır (Hansen 1-5). Bu öykü 1570'de François de Belleforest tarafından Histoires tragiques (Trajik Öyküler) adıyla beş cilt halinde Fransızcaya çevrilmiştir. Görüldüğü üzere, Belleforest'nin Saxo'nun metnini fazlasıyla genişleterek çevirdiği anlaşılmaktadır. Hamlet söz konusu olduğunda çok önemli bir diğerkaynak I. Elizabeth döneminde muhtemelen Thomas Kyd tarafindan 1589'da yazıldığı varsayılan ve günümüzde $U r$-Hamlet adıyla bilinen oyundur (Edwards, 1985, s. 1-2). Bu eser zaman içinde kaybolmuş ve günümüze ulaşmamıştır.

Bu çalışmada Hamlet'te Orta Çağ' da Danimarka sarayında görülen çürümüşlükve hastalık temaları ve bu temalarla ilgili imgeler üstünde durulacaktır. Shakespeare'in Hamlet oyununda devletteki, bireylerdeki ve doğadaki ahlaki ve fiziksel çürümeyi vurgulamak için görsel imgeler ve koku imgelerini çokça kullandığı görülmektedir. Oyunda Claudius'un erkek kardeşi Kral Hamlet’i öldürüp onun karısıyla evlenmesi sonucu devlet, birey ve doğa olmak üzere farklı düzlemlerde çürümeye ve bireylerin hastalıklı hallerine dikkat çekilmektedir. Dolayısıyla, hain bir kardeş katilinin ensestin sınırlarında gezinen günahkâr evliliği sadece bireylerdeki ahlaki çürümeye ve hastalıklı hallere işaret etmekle kalmaz, bu hareketin olumsuz etkilerinin ülkenin üstüne kara bir bulut gibi çöktüğü görülür. Orta Çağ' da yaygın olarak kullanılan devlet (body politic) metaforu bağlamında devlet ve insan bedeni (body natural) - özellikle hükümdarın bedeni- arasında analoji kurularak devletin başındaki kişinin sağlık durumunun ülkenin tüm kurumlarına yansıdığı düşünülürdü. Böylelikle başı temsil eden hükümdarın hastalıklı olması veya ahlaki çürümüşlüğü de devletin diğer organlarını olumsuz anlamda etkilemekteydi. Ayrıca, devletteki çürümüşlügün ülkenin bütününe, aileye, bireye kadar uzandığı görülür, hatta doğa da bu çürümüşlükten nasibini alır.

\section{Devlet'te Çürümüşlük ve Hastalık İzlekleri ve İmgeleri}

Oyun on dördüncü yüzyılda Danimarka'da geçer. Wittenberg Üniversitesi'nde öğrenci olan Prens Hamlet, babası Kral Hamlet'in ölümü üzerine ülkesine döner. Tabii burada Wittenberg'e yapılan gönderme anakronizmdir, yani bir tarih hatasıdır, çünkü Avrupa'nın en eski üniversitelerinden olan bu üniversite ancak 1502'de kurulmuştur. Hamlet mutsuz ve öfkelidir. Onun bu hali sadece babasının ölümünden kaynaklanmaz; kendisinin de belirttiği gibi babasının ölümünden henüz iki ay (I.ii.16) gibi kısa bir süre sonra annesi Gertrude'un tahta geçen amcası Claudius'la evlenmesi onu yalnızca tiksindirmekle kalmamış, melankolik bir ruh haline de sürüklemiştir. Claudius'un babasını öldürdüğünden şüphelenir ve bunu nasıl ispatlayacağını ve ondan nasıl intikam alacağını düşünür durur. Hamlet kararsızlık ve tereddüt içinde debelenedursun, amcası onun kendisi ve iktidarı için bir tehdit oluşturduğunu anlamakta gecikmez.

Erkek kardeşi tarafindan kalleşçe öldürülen, tahtına el konan ve katili karısıyla evlenen önceki Kral Hamlet'in hayaleti mezarında huzur bulamayıp, geceleri şatonun surlarında dolaşmaya ve intikamının alınmasını istemeye başlayınca, oğlu Prens Hamlet'in yakın arkadaşı Horatio'nun "Ülkemizin başında büyük bir felaket dolaşıyor” (I.i.9) sözleri Danimarka’yı bekleyen sıkıntıların bir önsemesi olarak düşünülebilir. Ne de olsa, ölülerin

'Ophelia "İki kere iki ayı bile geçti” ((III.ii.67) derken Kral Hamlet öldükten iki ay sonra evlenen Claudius ve Gertrude’un olayların geçtiği zamanda iki aydır evli olduklarına işaret etmektedir. 
dünyada dolaşması doğal değildir ve bu Danimarka krallığında bir şeylerin yolunda gitmediğinin işaretidir. Katolik inancında Araf kavramının yer bulmasına ve hayaletlerin Araf'la ilişkilendirilmesine rağmen, İngiltere ve Danimarka'da olduğu gibi Protestan ve Anglikan inancına sahip milletler Araf kavramını reddeder ve ne Cennet'te ne de Cehennem'de yer bulamayan, iki arada kalmıș bu acinası hayaletlerin kötücül ruhlar olduğuna inanır (Young, 2013, s. 97). Ancak, oyunun geçtiği zaman olan Orta Çağda, on dördüncü yüzyılda, İngiltere henüz Katolik bir ülkeydi. Aynı şekilde, Danimarka da 1536'da Katolik kilisesinden ayrılana dek Katolikti. Dolayısıyla, öldürülen Kral Hamlet'in intikam peşindeki hayaletinin ortalarda dolaşması halkın gözünde kabul edilebilir bir olgudur. Eski kralın cinayete kurban gitmesinden kaynaklanan olumsuz gelişmeler olacağına kuşku yoktur. Tıpkı Roma İmparatoru Sezar öldüğünde olduğu gibi:

Horatio: [...] - Yüce Sezar'ın düşüşünden hemen önce

Mezarlar boşalmıştı hep. Ölülerse kefenlere bürünmüş,

Roma sokaklarında çığlık çığlığa bağrışıyordu.

Gökte yıldızlar alevden kuyruklar takmış dolaşıyor,

Gökyüzünden çiğ yerine damla damla kan yağıyordu;

İşte şimdi de yerle gök bir oldu,

Korkunç olayların habercilerini gönderiyorlar ülkemize,

[...]

Yaklaşan uğursuz günlerin işaretini gösteriyorlar halkımıza. (I.i.10-11)

Bu durumun yanı sıra Horatio'nun belirttiği üzere "ülkedeki telaş ve kargaşanın" bir başka nedeni ise Kral Hamlet' in bir çarpışmada öldürmüş olduğu Norveç Kralı Fortinbras'ın oğlunun intikam için "Norveç sınırında, / Ordan buradan, bir sürü gözükara, başıbozuk toplamış" halde Danimarka'ya saldırmak için beklemekte oluşuydu (I.i.10). Hamlet, Danimarka' daki çürümüşlüğü evvelce güzel olan bir bahçenin artık yabani otlarla kaplanmış bakımsız haline benzetir (I.ii.16). Rönesans'ta çok kullanılan bu bahçe imgesi üzerinden Claudius ve ahlaken çürümüş olan diğer karakterler temizlenmesi gereken zararlı otlarla özdeşleştirilirler. Claudius'un Kral Hamlet'i öldürmesiyle başlayan devletteki, ülkedeki, bireylerdeki ve doğadaki çürümeyi kalenin surlarında nöbet tutmakta olan Marcellus da şu sözlerle vurgular: "Danimarka'da bir şeyler kokuşmuş" (I.iv.28). Bundan dolayıdır ki, metinde, "çok," "bol," ("Rank," 2018, para. AII.5) "bakımsız (bahçe)" ("Rank," 2018, para. AII.6) gibi başka anlamlarının yanında, sıklıkla "rahatsız edici kötü koku" anlamında kullanılmış olan "rank" sözcüğü ("Rank," 2018, para. AIII.12) karakterlerin hemen hepsinin etraflarını saran pis ve tiksindirici bir kokunun farkında olduklarını göstermektedir. Claudius suçunu ve günahını insan bedenine koşut olarak düşünülen devlete ve kurumlarına mikrop bulaştırmış, ülkeyi enfekte etmiştir. Sonuçta devlet, hasta düşmüştür. Spurgeon'un da belirttiği gibi oyunda "ülser, tümör gibi hastalıkla ilgili çeşitli imgeler Danimarka'nın ahlaken sağlıksız durumunu tanımlamaktadır" (2004, s. 316). Bu imgelerden bir tanesi de Hamlet'in Polonius'a "Güneş köpek leşini öptügünnde / Kurt ürediğine göre - "(II.ii.44) ifadesinde görülür. Güneşin altında duran köpek leşinde kurtlar üremiştir ve bu Danimarka'nın durumunun göstergesidir. Güneşle özdeşleştirilen Kral Claudius'un yüzünden ülke çürümüş bir gövde gibi kurtların istilasına uğramıştır. Ülkede cinayet, zina, sarhoşluk, casusluk, intikam, ihanet, güvensizlik kol gezmektedir. Doğa da bu çürümeden nasibini almıştır. Claudius ve Gertrude'unKral Hamlet öleli iki ay bile olmadan evlenmesiyle Danimarka tohuma kaçmış bir bahçeye döner. Aynı şekilde, Laertes, kız kardeşi Ophelia'ya Hamlet'in ilgisinin samimiyetine 
inanmaması konusunda nasihat ederken, oyunun başında devleti betimleyen otlarla kaplı bahçe eğretilemesini devam ettirerek şöyle der: "Daha goncaları açılmadan yaralar çiçek kurdu $[$ sic $] .{ }^{2}[\ldots]$ / Yapar yapacağını hastalık, bir kere bulaşmışsa eğer” (I.iii.22).

Oyunda çürümenin başı Claudius'tur. Bir başka deyişle, devletin kendisidir. Claudius, ağabeyi Kral Hamlet Cennet'i andıran bahçesinde uyurken yanına sokulmuş, onu kulağına zehir dökerek öldürmüştür. Kral Hamlet kendisini öldürmek isteyen Claudius'u şeytanla özdeşleşen ve kötülüğü simgeleyen Cennet'teki yılanla ilişkilendirir (I.v.29). Kral Hamlet'in bedeninde dolaşan zehir etkisini gösterdiğinde doğal olarak kralın bedeni sağlığını yitirir. Kralın hayaleti vücudunun geçirdiği değişimi şöyle anlatır: Hayalet: "Ve birden her yanım pul pul oldu, / Bir cüzzamlı gibi iğrenç bir kabuk bağladı / Pürüzsüz bedenim" (I.v.30). O zamanın anlayışına göre hükümdarların Tanrı tarafından göreve getirildiklerine inanıldığından Claudius'un Kral Hamlet'i öldürmesi sadece krala değil, Tanrı'ya da karşı işlenmiş bir suçtu. Kral, ülkeyi, devleti temsil ettiğine göre onun bedenindeki bozulma, sağlıksızlık bütün ülkeye ve insanlarına yansıyacaktır. Nitekim öyle de olur. Sarayın surlarında nöbet tutan asker bile "hiç de iyi değilim. Yüreğim katılıyor" (I.i.7) demektedir. Eski günlerde, Kral Hamlet zamanında düşmanlarının korktuğu güçlü bir ülke olan Danimarka artık zayıftır, çökmüştür. Bu durum komşularının da dikkatini çekmekte ve Norveç kralının oğlu Genç Fortinbras, Claudius'un belirttiği gibi, "değerimizi küçümseyerek, / Ya da sevgili kardeşimizin ölümüyle / Devletimizin, çözüldüğü, dağıldığı inancıyla / Bu durumdan çıkar sağlayabileceği hülyasına kapılmış" (I.ii.13), yasal anlaşmalarla babasının Kral Hamlet'e bırakmış olduğu toprakların tümünü geri istemekte, topladığı orduyla Danimarka'nın üzerine yürümeye hazırlanmaktadir.

Ülkedeki çürümüşlüğün tek nedeni Kral Hamlet'in zehirlenerek öldürülmüş olması değildir; yerine geçen ve "Ren şaraplarını bir dikişte boşalt[an]" (I.iv.25), içki ve sefahat düşkünü kardeşi Claudius'un kendisi ve gayrı meşru yönetimidir. Böylesi bir hükümdarın yönetiminde eskinin güçlü Danimarka'sının artık itibarı kalmamıştır. Bu durumu Hamlet şu sözleriyle vurgular: "Ülkeyi baştan başa saran bu uyuşturucu şenlikler / Bizi başka ülkelerin gözünde küçük düşürüyor. / Ayyaş diyorlar bize ve bizi domuzlarla kıyaslayıp / Şerefli adımızı lekeliyorlar" (I.iv.26). Claudius hırslı bir adamdır ve güce sahip olmak ve onu korumak için cinayet işlemek dâhil her şeyi yapabilecek bir kimsedir. Oyun boyunca Hamlet'in babasının katilini şu sözlerle tanımladığı görülür: "sefil”, "[e]li kanlı, sapık alçak! / Duygusuz, hain, ahlaksız, insanlık dışı, kahpe!" (II.ii.56), "katil ve alçak, / [...] / Kral kılığında düşkün bir soytarı, / Hem krallıkta hem yönetimde bir yankesici, / Rafın üstünden değerli tacı çalıp / Cebine koyan bir hırsız" (III.iv.84), “ahlaksız katil, lanetli Danimarkalı" (V.ii.131). Böylesi bir pisliğin Danimarka'y1 mahvetmesini istemeyen Kral Hamlet'in hayaleti oğlundan intikam almasını, bu ahlaksızlığa dur demesini ister. Hayalet: "Danimarka' da krallık yatağının / Akrabanın akrabayla yattığı / Bir şehvet döşeği olmasına izin verme" (I.v.31). Uzun tereddütlerden sonra Hamlet tiyatro oyuncularının Kral'a ve saraydakilere “Gonzago'nun Öldürülüşü” adlı oyunu oynamalarını ister. Bundaki amacı Kral Hamlet'in kardeşi tarafından öldürülüşüne benzer bir konu içeren bu oyunu izleyen Claudius'u, kendi yaptığına benzer sahnelerden etkilenmesini sağlayıp, cinayeti itirafa zorlamaktır. Hamlet'in bu amacında başarılı olduğu söylenemez. Ne var ki, Claudius ağabeyini öldürdükten bir süre sonra işlediği cinayetin korkunçluğunun kendi de ayırdına varır ve kilisede Hamlet onun şöyle dediğine kulak misafiri olur: "Oh, öyle iğrenç ki işlediğim suç / Kokusu göklere ulaşıyor" (III.iii.78). Devletin ve vatandaşlarının iyiliği için tüm yozlaşmanın başı olan kraldan kurtulmak lazımdır. Böylelikle Hamlet kendini sadece hayaletin emrettiği gibi babasının intikamını almakla değil, Danimarka'nın ekseninin şaştı̆̆ bu başıbozuk zamanda ülkesinin durumunu da düzeltmekle yükümlü hissederek kaderine isyan eder: "Zamanın geçmeleri hep firlamış yuvalarından; / Lanet olsun, onu onarmak için doğduğum güne” (I.v.34).

${ }^{2}$ Çeviridesorun vardır. [...] "yaralar çiçeği kurt” olmalıydı. 


\section{Bireylerde Çürümüşlük ve Hastalık İzlekleri ve İmgeleri}

\section{Hamlet}

Çürümüşlük ve hastalık izlekleri ve imgeleri sadece Claudius'la ilintili değildir. Hamlet de hastadır. Onun hastalığı bedensel değil, aklı ve ruhuyla ilgilidir. Amcasının gerçekten babasının katili olup olmadığı konusundaki şüpheleri onun içini kemirmekte ve intikam almak için harekete geçmesini engellemektedir. Marazi hale gelmiş olan kuşkuları onun sağlıklı düşünmesine izin vermez. Hamlet'in gerçekte deli olup olmadığ Rosencrantz ve Guildenstern'ın ve tiyatro oyuncularının önünde adeta deli olduğunu itiraf eder: "Ben yalnızca kuzey-batıda kaçığım" (II.ii.50). Rosencrantz'in krala söylediği gibi Hamlet "Kafasının biraz karışık olduğunu kabul ed[er]" (III.i.58). Durumunun farkında olduğundan Rosencrantz'a sorduğu sorulara ciddi cevaplar veremeyeceğini söyler; Hamlet: "Aklım hastalıklı çünkü” (III.ii.74) diye itirafta bulunur. Polonius, Hamlet'in babasının ölümü, amcasının ihaneti, annesinin sadakatsizliği ve babasının sözünü dinleyen Ophelia'nın kendisine uzak durması dolayısıyla Polonius onun karşılıksız aşk yüzünden delirdiğini iddia etse de ("Bu derdin kaynağı ve başlangıcı / Karşılıksız aşkta yatıyor." III.i.63), bunu ne kadar doğru olduğu kesin değildir. Genel kanı yaşanan olaylar nedeniyle Hamlet'in dengesini yitirmiş olduğudur. Esasen, Claudius'un kendisini ciddiye almaması ve bir tehdit unsuru olarak görmemesi için Hamlet'in deliyi sadece oynamakta olduğu düşünülebilir. Bu durum Claudius'un huzurunu kaçırmak amacıyla Hamlet'in ayarlamış olduğu tiyatro topluluğunun babasının ölümünü andıran bir oyun oynayacağı sırada Horatio'ya "Aklım yerinde değilmiş gibi görünmeliyim” demesinden de bellidir (III.ii.66). Zaten Hamlet' in oyunculukta ne denli hünerli olduğu oyunculara oyunculuk hakkında verdiği nasihatlerden anlaşılmaktadır (III.ii.63-65). Böylelikle zaman zaman ettiği manalı laflardan kimse onun neyi ne kadar bildiğini anlayamaz. Hamlet babasının yasını fazlaca uzatarak sürekli siyah giysiler içinde, melankolik bir şekilde Elsinore Şatosu'nun koridorlarında gezip durur. Karamsardır; dünya ona "[a]nlamsız, boş" gelir (I.ii.16). Dünyayı "şu darmadağın olmuş dünya" (I.v.31) olarak betimler. İçi kararmış olan Hamlet arkadaşları Rosencrantz ve Guildenstern'e "tüm neşem kaçtı, spor yapmayı bıraktım. Öyle bir ağırlık çöktü ki üstüme;" (II.ii.48) diyerek sıkıntısını ifade eder. Yaşamın anlamsızlığ 1 , ölümün kaçınılmazlığ1 onu mutsuz ve depresif kılmaktadır. Üçüncü perde birinci sahnede yaşamı sorguladığı ünlü "Olmak ya da olmamak" solilogunda onun intihara bile meyilli olduğu anlaşılır. Öte yandan, Claudius da "[a]teşli bir hastalık gibi dolaşıyor kanımda" (IV.iii.93) dediği yeğeni Hamlet'i sağlığını bozan bir mikropmuş gibi tanımlar. Ondan kurtulmak için Hamlet'i Rosencrantz ve Guildenstern'le beraber, sözde onun güvenliği için, İngiltere'ye yollar ve onun yanındakilere İngiliz kralına hitaben yazdığ 1 ve Hamlet'in öldürülmesini istediğini belirten gizli bir mektup verir. Ancak İngilizler Hamlet'i öldürdüklerinde iyileşebileceğini belirtir Claudius: “yap bu işi İngiltere. / [...] / Ve sen beni iyileştirmelisin" (IV.iii.93). Denize açıldıktan bir iki gün sonra bir korsan gemisine atlayıp, öldürülmekten kurtulan Hamlet, yeniden Danimarka'ya döner ve Horatio'yla buluşur. Yollarına çıkan iki soytarı kılığındaki mezar kazıcılarölümü adeta alaya alarak mezar kazmaktadırlar. Geçmişin Sezar, İskender gibi büyük isimlerinin artık toprak altında oluşlarıylayaşamın geçiciliği, bir sonu olduğu vurgulanır. Oyundaki çürümüşlük izleğinin altını çizen en önemli sahnenin beşinci perde birinci sahnedeki mezar kazıcılarının sahnesi olduğu söylenebilir. Bu sahnede ölümün kaçınılmazlığı, dünyanın geçiciliğivurgulanırken ölümün, çürümenin çirkinliği tüm çıplaklığıylaortaya konur. Ölü bedenleri yiyen solucanlar, Kral Hamlet'in çürümekte olan bedeninin betimlemesi, yine Kral Hamlet'in yıllar önce ölen soytarısı Yorick'in mezarın içinden çıkan kafatası bu izleğin altını çizen güçlü görsel imgelerdir. Ayrıca, ahlaki çürümüşlüğe örnek olarak zührevi hastalıkların yaygın oluşu vurgulanır. Bu bağlamda birinci soytarının şu sözleri dikkate değerdir: "[...] buraya gelen frengili cesetlerden bazıları daha yatırmadan dökülüyor" (V.i.116). Aslında soytarının bu sözleri I. Elizabeth zamanında toplumdaki ahlaki çürümüşlüğe anakronistik bir göndermedir. Bu sahnede mezar kazıcıların çalışması sırasında Hamlet ve yanındakilerin çürümüşlüğün pis kokusundan rahatsız oldukları görülür. Oyunun sonunda Hamlet babasını öldüren, annesini kendine eş yapmış olan Claudius'u öldürerek ödeşmesinin gerekliliğini yine bir hastalık imgesi yoluyla belirtir: Hamlet Claudius'u sağlıklı bir devletin bünyesini kemiren bir yaraya ${ }^{3}$

${ }^{3}$ Özgün metinde ağız ülseri anlamına gelen “canker” sözcüğü kullanılır. 
benzetir: "İçimizdeki bu yaranın / Azıp başkalarına da bulaşmasına izin vermek / Lanetlenmek değil de nedir? (V.ii.123). Devletin başı olarak Claudius'un tüm Danimarka'ya hastalığını bulaştırmasına engel olmaya çalışmak çok zorlu bir görevdir ve Hamlet bundan duyduğu büyük sıkıntıyı dile getirir.

\section{Gertrude}

Oyunda Kraliçe Gertrude'un duyguları ve amaçları çok belirgin değildir. Claudius'u gerçekte sevmekte midir? Kocasını onunla aldatmış mıdır? Kral Hamlet’i Claudius'la el birliği mi yaparak öldürmüşlerdir? Yoksa, alışık olduğu konumdan aşağıya düşmemek için mi kocasının ölümünden sonra kayınbiraderinin evlenme teklifini kabul edip, onunla evlenmiştir? Nedeni ne olursa olsun, bir kadının henüz iki ay bile geçmeden ölmüş kocasının erkek kardeşiyle evlenmesi rahatsız edici bir durumdur ve hem kadın hem erkek için ahlaki çürümüşlüğe işarettir. Kral Hamlet de karısının kendisinden sonraClaudius gibi bir zavallıyla neden evlenmiş olduğuna akıl erdiremez: Hayalet: "Böyle bir sevgiden nereye düştü? Benim yanımda / Hiçbir özelliği olmayan o zavallıya. / [...] / Yanında 1şıl ışıl bir melek olsa da / Göksel yataktan bıkar şehvet / ve leş aramaya çıkar sonunda" (I.v.30). Bir çok eleştirmen tarafından ensest olarak nitelendirilen bu beraberliği Kral Hamlet ancak Gertrude'un şehvet dürtülerine yenik düşmüş olmasıyla açıklayabilmektedir. Hamlet de yaşını başını almış annesinin hayvansı bir şehvetle Claudius'un yatağına girdiğinden babasıyla hem fikirdir ve annesine bundan dolayı utanması gerektiğini söyler. Hamlet: "Çünkü senin yaşında kanın kaynaması durulmuştur artık; / Uslanmıştır kanın, mantığın sesine kulak vermiştir; / [...] / Ama o akıl felç olmuş olmalı herhalde. / [...] / Ah, ne ayıp! Hani, yüzün kızarmıyor? ((III.iv.83). Annesinin amcasıyla ilişkisini betimlerken bu beraberliği pis kokular, hayvansılık, kokuşmuşlukla özdeşleştirir: "Pis kokulu terle sıvanmış bir yatakta yaşarken, / Herşeyinle kokuşmuş [...] sevişirken, / O iğrenç domuz ahırında" (III.iv.83). Hamlet, oyunun başından beri kullanmakta olduğu bahçe metaforundan bir kez daha yararlanarak kadın bedenini bahçeye benzetmekte ve annesine "Zararlı otları gübreleyip azdırma" (III.iv.85) diye uyarıda bulunurken ot imgesi üzerinden Claudius'a gönderme yapmaktadır. Babası Hamlet'in amcasından intikam almasını istemekle birlikte, annesine dokunmamasını söyler. Hayalet: Sakın annene el kaldırma. / Düşüncesiyle bile aklına leke sürme. / Göklerin adaletine bırak onu, / Bırak kendi yüreğindeki dikenler / Dalasın soksun onu" (I.v.31). Gerçekten de, kendisinin de belirttiği gibi Gertrude Claudius ile evlenerek işlediği günahtan dolayı ruhen çürümüştür, zayıf ve hasta düşmüştür: "Günah işleyen her insanda olduğu gibi, / En ufak bir olay / Hasta ruhuma sanki büyük bir felaketin öncüsüymüş gibi geliyor” (IV.v.96).

\section{Polonius}

Sarayın ileri gelenlerinden PoloniusOphelia ve Laertes'in babasıdır. Yaşının getirdiği nedenlerden dolay1 akli melekelerini kısmen yitirmiş olduğundan zihinsel anlamda hastadır. Hamlet'in ona atfen sarf ettiği, "Şu baş belası ihtiyar budalalar" (II.ii.45) sözlerini doğrularcasına unutkanlıktan muzdariptir. Bu hali Reynaldo'yla konuşmasında açıkça görülür. Polonius: "Ve sonra şöyle yapar, hımm..., şey, şey yapar- / Ne söylüyordum? Hay Allah! / Birş̧ey söyleyecektim. Nerde kalmıştım?” (II.i.36). Polonius da saraydaki entrikaların ve kokuşmuşluğun bir parçasıdır. Onun aile ilişkilerindeki yozlaşma kızına sevdiği adam konusunda baskı yapmasında, Ophelia'yı Hamlet'e karşı casusluk yapması için kullanmasında ve oğlu Laertes'in yaşadığı Fransa'da peşine casus takıp, ne işlerçevirdiğini öğrenmek istemesinde açıkça görülür. HizmetkârıReynaldo'ya Paris'te Laertes'i sorup soruştururken kullanması için verdiği taktiklerden şeref kavramı konusundaki anlayışının çarpıklığı açıkça görülür. Reynaldo'nun Laertes'in tanıdıklarının yanına yaklaştığında hemen onun hakkında sorular sormaya başlamamasını, önce Laertes'i tanıdığını belirten bazı ifadeler uydurmasını öğ̈tler:

POLONIUS: 'Biraz da kendisini tanırım,' dedikten sonra

'Ama çok iyi değil,' diyebilirsin,

$[\ldots]$ 
'Çok vahşi yaratılışlıdır, şunlara düşkündür,'

Diye devam edebilirsin. Sonra,

İstediğini uydur onun hakkında -

Aman dikkat et, şerefine leke sürecek bir şey olmasın.

İşte canım şöyle uçarı, deli dolu, başına buyruk gençlerin kaçamaklarından,

$[\ldots]$

REYNALDO: Oyun oynamak gibi, Lordum.

POLONIUS: Evet; yada içki, kılıç, ağız dalaşı, kavga,

kadın peşinde koşmak, gibi. [...]

REYNALDO: Lordum, şerefini lekelemez mi bu?

POLONIUS: Yok canım, biraz hafiften alırsın suçlarken. (II.i.35)

Gertrude konuşmak için odasına Hamlet'i çağırdığında Polonius neler olup bittiğini öğrenmek ve gerekirse kraliçeye yardım etmek için perdenin arkasına saklanır. Hamlet'in perdenin arkasındakini Claudius sanıp, kılıcını saplamasıyla ölür ve ölümünün halk arasında ve sarayda bir soruna neden olmaması için aceleyle gömülür. Claudius Hamlet'e Polonius'un ölüsünü nereye sakladığını sorduğunda, Hamlet "politikacı kurtlardan oluşan bir kurul şu anda tepesinde toplanmış bulunuyor" der ve onun solucanlar tarafından yenmekte olduğunu, cesedin çürümekte olduğunu söyler (IV.iii.91). Siyasetin çürümüşlüğüyle bedenin çürümesinin birlikte verildiği bu görsel imge yoluyla genel anlamda çürümüşlük vurgulanmaktadır.

\section{Laertes}

Eğitimi için çoğunlukla Fransa'da bulunan Laertes ise Claudius'un taç giyme töreni için Danimarka'ya gelmiştir. Bu ziyaret sonrası Danimarka'dan Fransa'ya geri dönerken kız kardeşi Ophelia'y1 Hamlet konusunda uyarır. Hamlet'in sevgisini samimi bulmayan, onun gelip geçici hevesler peşinde koştuğunu, kız kardeşiyle gönül eğlendirdiğini düşünen Laertes, kardeşine temkinli olmasını, bekâretini ve iffetini korumasını nasihat eder. Oyundaki hastalık ve çürümüşlük imgelerinin aksine Ophelia'yı bir çiçeğe benzetir; ancak tedbirsiz davrandığı takdirde çiçek kurtlarının bedenini sarıp, onu hasta edeceğini belirtir (I.iii.22). Laertes böylelikle insanın duygularına kapılıp, temkinli davranmazsagençliğinin çürüyebileceğini vurgulamaktadir.

Oyunda Laertes Hamlet'le karşılaştırılmaktadır. Hamlet, Polonius'u yanlışlıkla da olsa öldürdüğünde Laertes Hamlet'le aynı duruma düşer ve babasının katilinden intikam alma duygusuyla yanıp tutuşur. Ama Hamlet'ten farklı olarak tereddütlü davranmaz, hemen harekete geçer. Laertes Fransa'dan öfke içinde gelir. Ayrıca, Polonius'un öldükten sonra alelacele gömülmesi de halkı olduğu kadar onu da huzursuz etmiş ve dedikodular almış yürümüştür. $\mathrm{Bu}$ duruma, hastalık imgesinden yararlanarak Kral Claudius şu sözlerle dikkat çeker: "fısıltı tellalları sinekler gibi üşüşmüş kulağına, / Hastalık taşır gibi, babasıyla ilgili söylenti taşıyorlar” (IV.v.99). Claudius gelişen olaylar karşısında Laertes'i Hamlet'e karşı kışkırtır ama Hamlet'in bir mektup yazarak kaçmayacağını, hepsinin karşısına tek başına çıkacağını belirtmesi, sıkıntılar karşısında yüreğinin hasta düşmüş olduğunu ifade eden Laertes'i biraz da olsa rahatlatır ("Nasıl da 1sınıyor şu hasta yüreğim,” IV.vii.106). 


\section{Ophelia}

Oyundaki iki kadın karakterden biri olan Ophelia, Kraliçe Gertrude'un aksine masumiyetin simgesidir. Oyunda onca hastalık, çürümüşlük ve pis kokunun yer almasına rağmen, Ophelia çiçeklerle ve güzel kokularla özdeşleştirilir. Örneğin, Laertes'le onun mezarının başındayken Kraliçe "çiçek gibi kız" (V.i.118) diye onu betimler. Bir zamanlar kendisini sevmiş olan Hamlet'e inanmış ve babası onun Hamlet'in sevgisini karşılıksız bırakmış olmasına inansa da Ophelia'nın Hamlet'le ilişkiye girmiş olduğu, hatta ondan hamile kalmış olduğu düşünülebilir. İlişkinin zaman içinde çürümüş oluşuna işaret Hamlet'in ona vermiş olduğu ve zamanla solmuş olan çiçeklerdir. Ophelia'nınartık güzel kokularını yitirmiş olan çiçekleri Hamlet'e iade etmek istemesi (III.i.61) ortamın çürümüşlüğünün güzel başlamış bir ilişki üzerindeki yıpratıcı, yok edici etkisini vurgulamaktadır. Sonuçta, babası Polonius'un ölümündenduyduğu kederve Hamlet'in ilgisizliği Ophelia'yı bunalıma sürükler ve akli dengesini yitirir. Sarayın koridorlarında elinde hayalî otlar ve çiçeklerle manasız sözler ve şarkılar söyleyerek dolaşır. Üzüntülerin kendisini bitirdiğini, artık metaforik anlamda bir ölü olduğunu söyler:

KRALİÇE: Ah, zavallı kız! / Ne demek bu şarkı?

OPHELİA: [...] Öldü gitti o şimdi bayan,

Artık o öldü gitti. (IV.v.97)

Bir kızla oğlanın aşkını anlattığı bu şarkıların biri yoluyla Ophelia'nin Hamlet'le cinsel ilişkiye girdiği anlaş1lır:

OPHELİA: Koştu kapısını açtı odanın

Tuttu elini, kızı içeri aldı

O kapıdan artık bir kız çıkmadı. (IV.v.97)

[...]

'Alırım sen, demiştin hani

Kızlığımı bozmadan önce.' (IV.v.98).

Şarkılarını bitirdikten sonra Ophelia orada bulunan saraylılara karakter ve kişiliklerine uygun bulduğu otlardan ve çiçeklerden verir. Aklı başında olmamasına rağmen bu konudaki seçimlerinin dikkat çekici ölçüde akıllıca ve anlamlı olduğu görülür. Bundan Shakespeare'in diğer pek çok eserinde de görüldüğü gibi bitkileri ve özelliklerini oldukça iyi tanıdığı anlaşılmaktadır. Hamlet'te de Ophelia'nın verdiği bu bitkilerin gelişigüzel seçilmiş olmadıkları anlaşılmaktadır. Ophelia herkese kendi karakterini vurgulayan otlar ve çiçekler verdiği gibi, onun ilgili karakterin kötü özelliklerini iyileştirici bitkileri sanki bir ilaç verir gibi vermekte usta olduğu görülür. Bahçesi olan her soylu kadın gibi Ophelia'nın bitkilerin sağaltıcı özellikleri hakkında bilgi sahibi olduğu ve şifalı bitkileritanıdığı anlaşılmaktadır (Tigner, 2012, s. 98). Siyasi ve ahlaki anlamda çürümüş ve hastalıklı olan Danimarka'nın göklere yükselen pis kokusuna tezat oluşturacak şekilde Ophelia'nın verdiği bitkilerin çoğu güzel kokuludur (Tigner, 2012, s. 99) ve bunların sadece verilen kişilere değil, Danimarka'ya da iyi geleceği, onu iyileştireceği düşünülebilir.

Sahne yönergesiyle açıkça belirtilmediğinden Ophelia'nın kime hangi kokulu ot veya çiçeği verdiği açık değildir. Ancak, dramaturji çalışmasıyla kime hangi çiçeği verdiği yüzyıllardır artık neredeyse geleneksel hale gelmiştir. Shakespeare'in zamanında okuyucu/izleyicinin çiçeklerin dilinden anladığı, çiçeklerinadeta onlarla konuştuğu bilinmektedir (Webster, 2008, s. 107). Bu durumda Ophelia'nın Laertes'e biberiye ve hercai menekşe vermesi anlamlıdır. Cenazelerde ölü unutulmasın diye tabutun üstüne biberiye (rosemary) konurdu (Goody, 1993, s. 284; Olderr, 1986, s. 173) ve Ophelia'nın bu otu Laertes'e vermesi öldüğünde kendisini unutmaması içindir. Belki de bu otu o sırada sahnede bulunmayan ama hayalinde canlandırdığ̣ Hamlet'e aynı amaçla sunar. Dolayısıyla, bu hareketiyle ölümünü (belki de intiharını) önsemektedir. Ayrıca, Laertes'e kendisini düşünmesi için hercai menekşeler(pansy)verir. Hercai menekşe aynı zamanda üzüntü ve kederi simgelediğinden (Kerr, 1997, s. 55-56; Grabau), bu seçim Ophelia'nın ölümünün Laertes'i ne denli üzeceğine bir işarettir. İlginçtir ki, hercai menekşelerin o devirde cinsel temasla 
bulaşan hastalıklara iyi geldiği (Breverton, 2011) düşünüldügünden Ophelia'nın bu çiçeklerden Laertes'e vermesi belki de erkek kardeşinin Fransa'daserbest bir cinsel yaşamı olduğunu ima etmekte ve bunun sonucu kaptığı hastalığa dikkat çekmektedir. Metinde rezene (fennel) ve haseki çiçeğinin (columbine) alıcıları açıkça belirtilmemiștir. Ophelia bu otuve çiçeği Claudius'a da Gertrude'a da vermiş olabilir çünkü bu bitkilerin simgeledikleri özellikler her iki karaktere de uymaktadır. Rezene aldatma, hilebazlığın, düzenbazlığın ve ikiyüzlülüğün simgesiyken (Kerr 85; Grabau; Olderr, 1986, s. 85), haseki çiçeği nankörlük, vefasızlık ve evlilikte ihaneti simgeler (Kerr 49; Grabau; Olderr, 1986, s. 56). Ophelia, Kraliçe Gertrude'a üzüntü ve pişmanlığı simgeleyen sedefotu (rue) (Kerr 50) verir; Gertrude yaptığı yakışıksız evlilikten dolayı gerçekten pişman mıdır bilinmez. Ophelia kendine de bu çiçekten biraz ayırır çünkü o da üzüntülüdür ve anlaşılan Hamlet'e kandığı ve onunla yaşadığ 1 ilişki yüzünden pişmandır. Bu çiçeğin işledikleri günahlardan dolayı ${ }^{4}$ samimiyetle pişman olanlara Tanrı tarafından bağışlanacaklarının işareti olmas1 (Kerr 50; Olderr, 1986, s. 174) da dikkat çekicidir. Bununla beraber, o zamanlarda sedefotu hamile kadınlarda istenmeyen çocuğu düşürmek için kullanılmaktaydı (Breverton, 2011, s.y; Riddle, 1998, s. 48-49). Dolayısıyla, bu çiçeğin simgesel anlamı o günün okuyucusu/izleyicisi tarafından bugüne göre çok daha anlaşılır olduğundan, Gertrude'un Kral Claudius'dan ve/veya Ophelia'nın Hamlet'ten hamile oldukları ve bebeklerini düşürmek istedikleri düşünülebilir. Ophelia ayrıca Gertrude'a "Bak bir papatya" (IV.v.102) diyerek çiçeğe işaret eder ama vermez. Masumiyetin ve saflığın sembolü olan papatyaya Gertrude layık değildir. Belki de her türlü ağrı ve yarayı iyileştirdiğine inanılan (Breverton, 2011, s.y. $)^{5}$ bu çiçeği Gertrude'a vermeyerek Ophelia onun yaralı ruhunun iyileşmesini istemediğini gösterir. Ophelia mor menekşe de getirmek istediğini ama babası ölünce menekşelerinin kuruyup, solduklarını söyler. Çünkü sadakati ve erdemi simgeleyen güzel kokulu mor menekşeyi (Grabau; Olderr, 1986, s. 114) orada kimse hak etmemektedir.Shakespeare'in eserlerine genel olarak bakıldığında doğduğu ve büyüdügü yer olan Stratford-upon-Avon ve civarında çokça görülen kokulu mor menekşelere oldukça fazla yer verdiği (Ellacombe, 2017, s. 330), en az kullandığı çiçeklerden birinin ise papatya (Ellacombe, 2017, s. 76) olduğu görülür. Öte yandan, Ophelia sahneden çıkmadan önce "tatlı şeker Robin'den başka kalmadı neşem" (IV.v.102) derken "ragged robin" (lychnis flos-cuculi)adlı karanfilgillerden genelde pembe olan bir kır çiçeğini kastetmektedir. Bu pembe çiçeklerle ilgili olarak konu hakkındaki hemen her kaynakta onların farkındalılığı, zekâ kıvraklığını ve ince bir nüktedanlığı simgelediği belirtilmektedir (Olderr, 1986, s. 165; Dietz, 2015, s. 541). Bu durumda Ophelia'nın Hamlet gibi, deliyi zekice oynayarak çiçek verme sahnesinde karşısındakilerle inceden inceye eğlendiği ve neşelendiği düşünülebilir.

Hastalık, çürümüşlük ve pis kokuların kol gezdiği Danimarka'da çiçeklere bir başka gönderme yine Ophelia üzerinden yapılmaktadır. Saraylılara verdiği bitkiler gibi kendine yaptı̆̆ 1 taçdaki bitkilerin de bir anlamı vardır. Sarayın tüm çürümüşlüğü ve yapaylığına karşın bu sahne tabiatın tazeliğini ve doğallığını yansıtır. Gertrude onun dere kenarına gittiğini anlatır. "Çiçeklerden renk renk taçlar yapmış orda kendine, / Isırganlardan, papatyalardan ve uzun mor çiçeklerden-" (IV.vii.110). Esasen Ophelia'nın tacında dört bitki vardır: bunlardan biri Türkçede birebir karşılığı olmayan bir yabani karanfil türü olan "crowflower"dır. Bu çiçek bazı kaynaklarda "ragged robin" (lychnis flos-cuculi) ve altıntabak veya acı düğün çiçeği (buttercup) (Thomas ve Faircloth, 2014, s. 93) olarak verilir. Vefasızlığı simgeleyen bu bitki (Dietz, 2015, s. 738; Grabau) Ophelia'nın Hamlet'le gerçekleşmeyen düğünü için duyduğu üzüntüye işaret eder. Genç bir kızın tacında bulunması garipsenecek olan 1sırgan otları ise insanı dalayarak canını acıttı̆g için Ophelia'nın yaptığı hatalardan dolayı kendi kendisine verdiği bedensel bir cezadır. Aynı zamanda, kafasında bu dikensi otlarla İsa'yı andırır ve onun gibi başkalarının günahları yüzünden de acı çekerek ölür (Tigner, 2012, s. 100). Taçtaki papatyalar geleneksel olarak tüm bu pisliğin ortasında Ophelia'nın masumiyetini vurgular. Taçtaki bir diğer çiçek ise mor bir yabani orkide çeşidi olan "long purples"dır (orchis morio) (Ellacombe, 2017, s. 157). Görüntüsüyle erkek cinsellik organını, dolayısıyla cinselliği, çağrıştıran bu bitki (Tigner, 2012, s. 101) Ophelia'nın Hamlet'le yaşadığı cinsellik sonucu bedeninin cinsel bir nesneye dönüşmüş olmasını anımsatmaktadır (Tigner, 2012, s. 101). Aynı zamanda, yine görüntüsü nedeniyle, "Dead Men's Fingers" (Ölü Adamların Parmakları) olarak da bilinen (Ellacombe, 2017, s. 157; Tigner, 2012, s. 101) bu

${ }^{4}$ Ophelia'nın evlenmeden önce cinsel ilişkiye girmiş olması günah olarak kabul edilmekteydi.

${ }_{5}^{5}$ Breverton da Hamlet 'te olduğu gibi yara anlamına gelen “canker” sözcüğ̈̈nü kullanmaktadır. 
yabanıl çiçek Ophelia'nın ölümünün yakın olduğunu işaret etmektedir. Çiçeğin her iki sembolik anlamı bir araya getirildiğinde Ophelia'nın Hamlet'le yaşadığı ve o dönemde toplumsal ve dinînormlara ters düşen evlilik dışı cinselliğin onun intiharına neden olan sebeplerden biri olduğu anlaşılmaktadır. Yaptığ tacı derenin kenarındaki söğüt ağacının eğilen dallarına takmak için ağaca tırmanırken ince dal onun ağırlığını taşımaz ve dalın kırılmasıyla Ophelia suya düşer. Tabii bu arada söğüt ağacının melankoli, yas, üzüntü ve mutlu sona ulaşamamışbir aşkı simgelediği (Dietz, 2015, s. 789-790) unutulmamalıdır. Hamlet gibi, yaşadığı derin üzüntüler nedeniyle intihara yatkın olan Ophelia kurtulmak için hiçbir çaba göstermez, edilgen bir biçimde kendini suya bırakır ve elbisesinin ağırlığıyla suya gömülür ve boğulur gider. Masumiyetine rağmen o da etrafındaki onca çürümüşlügüü bir parçası olmaktan kendini kurtaramaz: Kraliçe: "Suyu içtikçe ağırlaşan giysileri / Zavallı kızcağızı türkülerinden söküp almış / Ve ölümün balçığına çekmiş" (IV.vii.110) der. Çürümüşlük ve hastalık imgeleriyle dolu metinde bu durumun tersine Ophelia'nın ölüm sahnesinde çiçekler vardır. Kraliçe onun açık olan mezarının üzerine çiçekler serper. Ancak, Ophelia'nınintihar etmeyi seçtiği düşünüldüğünden kapsamlı bir dinî törenle gömülmesine izin verilmez; sessiz sedasız ve soyluluğuna yaraşmayan bir biçimde defnedilir.

\section{Doğada Çürümüşlük ve Hastalık İzlekleri ve İmgeleri}

Bazı karakterlerin ahlaki çürümüşlükleri ve Claudius ve Gertrude'un aykırı beraberliğiyle evliliğin kutsallığına düşen gölgeden devletin yanı sıra doğa da nasibini alır. Vaktiyle bir Cennet bahçesini andıran Danimarka'da başlayan çürümeyi ve ülkenin kötü durumunu Hamlet, yaptığ1 eğretilemeyle, çorak bir bahçeye benzetir; ahlaken çürümüş ve hastalıklı karakterler bir bahçenin yok olmasına sebep olabilecek zararlı otlar gibi ülkeyi çoraklaştırmıştır: “[...] her yanını ot bürümüş bir bahçe / Tohuma kaçmış baştan başa. Doğada çürümüş, kokuşmuş ne varsa / Onlara kalmış her yer. Böyle mi olacakt1-” (I.ii.16). Hamlet'in söylediği gibi hava ve doğa da kirlenmiştir ve bu durum onu bunaltmaktadır: "şu hava [...], şu [...] gökkubbe [...] bunların hepsi bana tepeme üşüşmüş iğrenç ve hastalık taşıan bulutlar gibi geliyor yalnızca" (II.ii.48). Hamlet, dünyanın bu hastalıklı hale düşmesine sebep olan insanoğluna duyduğu güven ve sevgiyi de yitirir: "Hoşlanmıyorum artık insanoğlundan" (II.ii.48). Böylesi insanların ahlaksızlıkları nedeniyle dünya "çorak" (II.ii.48) bir yere dönmüştür. Dolayısıyla, Hamlet annesini ahlak dışı, utanç verici davranışı nedeniyle dünyanın hastalıklı halinden sorumlu tutar: "Gökkubbenin yüzü kızarır; şu kaskatı kaynaşmış kütle, / Yüzü kıpkızıl yanarken, kıyamet günü eşikteymiş gibi, / Dehşetten hasta düşer" (III.iv.82) der. Yine üçüncü perdede annesinin yatak odasında geçen sahnenin devamında Hamlet konuşmasında yara ve bahçe imgelerini kullanarak kraliçeyi hareketlerine dikkat etmesi için uyarır: "Merhem yüzeyde bir zar çekip kabuk bağlatabilir, / Ama çürüme sürer ve yara azar için için / Ve yayılır görünmeden. [...] / Zararlı otları gübreleyip azdırma" (III. iv.85). Burada sadece doğanın değil, yaşanan ahlak dışı cinsellik nedeniyle bir objeye indirgenmiş kadın bedeninin de dikkatli olunmazsa çürümeden nasibini alacağı ima edilmektedir.

\section{Elizabeth Dönemiyle Koşutluklar}

Zamanın oyun yazarları kendilerini ve eserlerini destekleyecek bir hami bulamama endişesinin yanı sıra sansürden kaçmak için ve başlarını derde sokmak istemediklerinden İngiliz hanedanına doğrudan değinmez, hikâyelerini geçmiş zamanda kurgular, uzak ülkeler ve uzak ülkelerin hükümdarları hakkında yazarlardı. Dolayısıyla, ele alınan kişi ve olaylarla günün kişi ve olayları arasında bir bağ kurmak okuyucuya/izleyiciye bırakılırdı. On dördüncü yüzyıl civarında Danimarka'da geçen bu oyun ile on altıncı yüzyılın sonu - on yedinci yüzyılın başında İngiltere'deki siyasi ve ahlaki durumlar arasında birebir olmasa da bazı paralellikler dikkat çekmektedir.

Hamlet'in 1598-1602 arasında bir tarihte yazıldığ1 ve I. Elizabeth'in 1603'de öldüğü düşünülecek olursa o tarihlerde Kraliçe Elizabeth'in altmış beş-altmış dokuz yaşları arasında ve ülkeyi neredeyse yarım yüzyıldır yönetmekte olan yaşlı bir kadın olduğu görülür. Tigner, Gertrude'un gövdesini otlar bürümüş bedeniyle I. Elizabeth arasında bağ kurar (2012, s. 97). İngiltere'ye o zamana kadar tarihinin en 
parlak dönemini yaşatmış olan I. Elizabeth, Geç Elizabeth Dönemi olarak adlandırılan 1585-1603 yılları arasında saltanatının sonuna gelmiştir ve bazı keyfî politikaları nedeniyle iktidarının zayıflamış olduğu, saraylıların ve halkın muhalefetiyle karşılaștığı görülür. Ayrıca, kraliçenin gözüne girip, siyasi ve maddi menfaatler elde edebilmek için Polonius, Rosencrantz ve Guildenstern'ı çağrıștıran bazı saraylılar, başta sürekli birbirlerinin kuyusunu kazan Devereux ve Cecil aileleri olmak üzere, iktidar savașı içindeydiler ve bunun için her yolu mübah görüyorlardı. Dolayısıyla, soylular arasındaki ahlaki çürümüşlük devlete de yansımakta ve onu güçsüz düşürmekteydi. Ahlaki çürümüşlüğe bir başka örnek ise Elizabeth'in evlenmemesine rağmen serbest bir özel yaşamı vardı ve bu konu tartışmalı da olsa, Walter Raleigh, Robert Devereux ve Robert Dudley gibi birkaç sevgilisi olduğu varsayılırdı. Bu da bir yerde Claudius'un şehvete düşkünlügünü akla getirmektedir. Bunlar yetmezmiş gibi, İngiltere'deki siyasi kokuşmuşluğun bir parçası olarak I. Elizabeth çok sevdiği ve bazı kaynaklarda oğlu olabileceği ileri sürülen II. Essex Lordu Robert Devereux'yu kendisine ihanet ederek ayaklandığ için idam ettirmek durumunda kaldı. Essex'in bu ihaneti en yakınına, ağabeyine, ihanet eden Claudius'unki gibi kabul edilemez, ahlak dışı bir harekettir. Kraliçenin sadece ülke içinde değil, dışında da İspanya ve Fransa gibi düşmanları vardı. Bu durum da Hamlet'te ülke içinde Claudius'un Kral Hamlet ve Prens Hamlet'e olan düşmanlığını, ülke dışında da Norveç'in Danimarka'ya karşı olan düşmanlığını çağrıștırmaktadır. Kraliçe, başta William Cecil olmak üzere danışmanlarının onca ısrarına rağmen evlenmediği, çocuk sahibi olmadığı için kendisinin yerine geçecek bir veliahtı yoktu. Tudor hanedanının ve İngiltere'nin geleceğinin pek belli olmadığı bu karışık ortamda kraliçenin iktidarını daha da zayıflatan yoz siyasi çekişmeler yaşanmaktaydı. Hamlet'te de tahtta oturan Claudius'un bunu hak edip etmediği, tahtın gerçek sahibinin Hamlet olması gerektiği üzerinde durulur. Sonunda, I. Elizabeth öldüğünde mensubu olduğu Tudor hanedanının saltanatı devam edemedi ve taht bir yabancıya, İskoç kralı VI. James'e kaldı. Kraliçenin kuzeninin oğlu olan Stuart hanedanı mensubu James İngiltere tahtına I. James olarak oturdu. Tarihler dikkate alındığında, Hamlet'in I. James tahta çıkmadan yazıldığı düşünülebilir. Benzer şekilde Hamlet oyununda da bir yabancı tahta oturur: Danimarka asıllı bir kral yerine Norveç asıllı Fortinbras'ın Danimarka kralı olmasıyla oyun son bulur.

\section{Sonuç}

Hamlet sona erdiğinde sekiz kişi ölmüştür. Rosencrantz ve Guildenstern kendisine ihanet ettikleri için Hamlet'in İngiltere kralına yolladığ 1 sahte mektuptaki tavsiye sonucu orada idam edilmişlerdir; bu çürümüşlügün ortasında sıkışıp, kalmış olan zavallı Ophelia ise dayanamayarak canına kıyar. Bu ölümler sahne dışında gerçekleşir. Hamlet kral sandığı saray içi entrikalara meraklı Polonius'u yanlışlıkla öldürür; Gertrude kralın Hamlet için hazırladığı zehirli şarabı yanlışlıkla içer ve ölür; Laertes ve Hamlet zehirli kılıçla birbirlerini yaralar ve ölürler ve her şeyin sorumlusu Claudius ise Hamlet'in ağzına zorla boşalttığ zehirli şarabı içerek ölür. Bu kişilerin, Ophelia hariç hepsi, sebep oldukları veya bulaştıkları ahlaksızlık, çürümüşlük nedeniyle ölmüşlerdir. Diğer oyun kişilerinin özdeşleştiği hastalık ve çürümüşlük imgelerinin tersine, çiçek imgeleriyle akılda kalan masum Ophelia, öldürülmemiş, çevresindeki pisliğin, çamurun, çürümüşlüğün içine ister istemez çekilerek yaşamını yitirmiştir. Oyunun sonunda devleti temsil eden Hamlet ailesinden Claudius ve Gertrude'un, devlete yakın olan Polonius ailesinden Polonius ve Laertes'in ve devlet için çalışmış olan Rosencrantz ve Guildenstern'ın ölümleriyle, Danimarka çürümüş bireylerinden temizlenir. Devleti çürümüşlükten arındırmak ve düzeni sağlamak için yola çıkmış olan Hamlet de kendini bulduğu bu çürümüşlügüun içinde ellerini kana bulamış olur. Düzeni sağlamak için ironik bir biçimde adam öldürür (Ribner, 1960, s. 69). Bu nedenle olsa gerek oyunun sonunda onun da Danimarka'nın iyiliği için ölmesi gerekmiştir.

Oyunun sonunda hayatta kalan iki kişi sahne dışındaki askeri başarılarından haberdar olduğumuz genç ve güçlü Fortinbras ile Hamlet'in "tanıdığım kişiler arasında / Senin gibi şereflisine raslamadım" (III.ii.65) diye övdüğü, saray çevresinde tek güvendiği dürüst kişi, arkadaşı Horatio'dur. Horatio, ardında "yaralı bir isim"

kalmasını arzu etmeyen (V.ii.132) Hamlet'in isteği üzerine, gelecek nesillere bu hikâyeyi anlatacaktır. Öte yandan, Hamlet'in de onayladığı üzere Fortinbras Danimarka'nın başına geçer. Hamlet'i öven Fortinbras, onun 
bir soylu ve bir askere yaraşır bir biçimde gömülmesini sağlayacaktır. Bir ülkenin dirliğinin başındaki yöneticinin meşruluğuyla, yönetici kademedekilerin ve halkın ahlaken sağlam olmasıyla koşut olduğu düşünüldüğünden, bu durumda Danimarka'nın yeniden eski güçlü günlerine döneceği anlaşılmaktadır. Oyun, Danimarka'nın aldatmaca, güç savaşları, iki yüzlülük, iktidar hırsı, intikam, ihanet, delilik, ahlaksızlık gibi siyasi ve kişisel alanlarda görülen çürümüşlüklerden ve hastalıklı durumlardan temizlenmesi ve dirliğin ve ahenkli, sağlıklı bir dünyanın sağlanmasıyla sona erer.

\section{Kaynakça}

Breverton, T. (2011). Breverton's complete herbal: A book of remarkable plants and their uses. Londra: Quercus Publishing.

Dietz, S. T. (2015). Floriography today: The symbolic meanings \& the possible powers of trees. https//: fayshoneshire.com adresinden erişildi.

Edwards, P. (Ed.). (1985). Hamlet, Prince of Denmark. Cambridge: Cambridge UP.

Ellacombe, H. N. (2017). The Plant-lore and garden-craft of Shakespeare. Mineola, NY: Dover Publications.

Goody, J. (1993). The culture of flowers. Cambridge: Cambridge UP.

Grabau, L. (2013). Hamlet Dramaturgy: Ophelia's flowers. https://hamletdramaturgy.wordpress.com/2013/02/20/ophelias-flowers adresinden erişildi.

Hansen, W. F. (1983). Saxo Grammaticus and the life of Hamlet. Lincoln, NE: U of Nebraska Press

Kerr, J. (1997). Shakespeare's flowers. Boulder, CO: Johnson Books.

Olderr. S. (1986). Symbolism: A comprehensive dictionary. (2 bs.). Jefferson, N.C.: McFarland Publishing.

Rank. (2018). Oxford English dictionary. http://www.oed.com/ adresinden erişildi.

Ribner, I. (1960). Patterns in Shakespearean tragedy. New York: Barnes and Noble.

Riddle, J.M. (1998). Eve's herbs: A history of contraception and abortion in the west. Cambridge, MA: Cambridge UP.

Shakespeare, W. (1982). Hamlet. (B. R. Bozkurt, Çev.). Ankara: Hacettepe Üniversitesi Yayınları.

Spurgeon, C. (2004). Shakespeare's imagery and what it tells us. Cambridge: Cambridge UP.

Thomas, V. ve Faircloth, N. (2014). Shakespeare's plants and gardens: A dictionary. Londra: Bloomsbury Publishing.

Thompson, A. ve Taylor, N. (1996). William Shakespeare, 'Hamlet'. Plymouth, UK: Northcote House in Association with the British Council.

Tigner, A. L. (2012). Literature and the Renaissance garden from Elizabeth I to Charles II. Londra ve New York: Routledge.

Webster, R. (2008). The Encyclopedia of superstitions. Woodbury, MN: Llewelleyn Publications.

Young, F. (2013). English catholics and the supernatural, 1553-1829. Londra ve New York: Routledge. 